\title{
The Speed of Cocaine Delivery Determines the Subsequent Motivation to Self-Administer the Drug
}

\author{
Ellie-Anna Minogianis', Daniel Lévesque ${ }^{2,3}$ and Anne-Noël Samaha*,1,3 \\ 'Department of Pharmacology, Faculty of Medicine, Université de Montréal, Montreal, QC, Canada; ${ }^{2}$ Faculty of Pharmacy, Université de \\ Montréal, Montreal, QC, Canada; ${ }^{3}$ CNS Research Group, Faculty of Medicine, Université de Montréal, Montreal, QC, Canada
}

\begin{abstract}
The rapid delivery of drugs of abuse to the brain is associated with an increased likelihood and severity of addiction. Here we evaluated the hypothesis that rapidly delivered cocaine facilitates the addiction process by promoting the development of enhanced motivation for the drug. Rats lever-pressed for cocaine delivered intravenously over 5 or 90 s under fixed ratio (FR) during 6-h sessions. The motivation for cocaine was subsequently assessed using a progressive ratio (PR) schedule, where each successive drug injection cost an exponentially greater number of lever presses, until the cessation of responding. Throughout all self-administration sessions, all rats could only take one injection every 90 s. The 5 -s groups self-administered more drug than the 90 -s groups across the FR sessions. Under PR, animals that had chronically self-administered rapidly delivered cocaine took more cocaine across a range of doses and regardless of whether the drug was delivered over 5 or 90 s during PR testing. The speed of delivery also determined the long-term neurobiological impact of cocaine. Fourteen days following cocaine withdrawal, caudate-putamen D2 levels were decreased only in the 90-s rats, and quinpirolemediated $\mathrm{G} \alpha_{\mathrm{i} / \mathrm{o}}$-protein activation was increased to a greater extent in the 90 - vs 5 -s rats. Thus, rapid delivery promotes the pursuit of cocaine in the face of rising costs and alters cocaine-induced changes in striatal D2 receptor number and function. As such, rapidly delivered cocaine might facilitate addiction because it more readily alters brain motivation circuits in ways that contribute to the compulsive pursuit of the drug.

Neuropsychopharmacology (2013) 38, 2644-2656; doi:10.1038/npp.2013.173; published online 7 August 2013
\end{abstract}

Keywords: speed of drug delivery; cocaine; extended access; progressive ratio; intravenous drug self-administration; dopamine D2 receptor

\section{INTRODUCTION}

It is thought that 'The development of addiction depends on the interaction of agent, host and environment...' (O'Brien, 2008). Much research has shown that 'host'- and environment-related factors can modulate the transition from controlled drug use to addiction (Badiani and Robinson, 2004; Le Moal, 2009). Much less attention has been paid to characteristics of the 'agent' and how these might accelerate or delay the progression to addiction. One such characteristic is the speed at which a drug reaches its target sites in the brain. Addiction to cocaine, amphetamine, methamphetamine, nicotine, or heroin is more likely and more severe in individuals who smoke or inject these drugs than in individuals who use slower routes of administration (eg, intranasal, oral, or transdermal administration). Individuals who smoke or inject drugs use drugs more frequently, for a longer time, spend more money on drugs, report a greater loss of control over drug taking, and are more likely to

*Correspondence: Dr A-N Samaha, Department of Pharmacology, Faculty of Medicine, Université de Montréal, C.P. 6128, Succursale Centre-ville, Montreal, QC H3C 317, Canada, Tel: +514343 61।1 x. 32788, Fax: + 514343 229I, E-mail: Anna.samaha@umontreal.ca Received 20 March 20 I3; revised II July 20 13; accepted I 5 July 20 I3; accepted article preview online 18 July 2013 overdose (Barrio et al, 2001; Carpenter et al, 1998; Ferri and Gossop, 1999; Gossop et al, 1992; Hatsukami and Fischman, 1996; Hughes, 1989; Rawson et al, 2007; Winger et al, 1992).

Rapidly administered drugs are hypothesized to be more addictive, because they are more pleasurable such that the likelihood of continuing or escalating drug use is increased (de Wit et al, 1993; Hatsukami and Fischman, 1996). Indeed, rapid delivery enhances the positive subjective effects of drugs (Abreu et al, 2001; de Wit et al, 1993; Kollins et al, 1998), and this could contribute to drug use. A related hypothesis is that rapidly administered drugs are more addictive, because they are more reinforcing (Balster and Schuster, 1973; Kato et al, 1987; Panlilio et al, 1998). The idea is that because drug effects are more immediate with rapid drug delivery, associations formed between drugtaking behaviors and ensuing drug effects are stronger and the likelihood of repeating these behaviors is increased.

However, animal studies on reinforcing efficacy have produced inconsistent findings. Some show that rapid intravenous delivery enhances the acute reinforcing effects of drugs (Balster and Schuster, 1973; Kato et al, 1987; Panlilio et al, 1998; Schindler et al, 2011; Wakasa et al, 1995; Woolverton and Wang, 2004), and others show that it does not (Crombag et al, 2008; Liu et al, 2005; Sorge and Clarke, 2009). The reasons for the discrepancy are not clear. However, the procedures often used (limiting drug access to 
1-3 h/session; (Crombag et al, 2008; Panlilio et al, 1998; Pickens et al, 1969; Schindler et al, 2011; Sorge and Clarke, 2009)) are known to promote stable patterns of drug intake, rather than the progressive and deteriorating patterns of drug-taking behavior that define addiction (Ahmed, 2012; Roberts et al, 2007). Recently, the influence of the speed of drug delivery on drug reinforcement has been assessed using extended self-administration (SA) sessions (Wakabayashi et al, 2010), where animals self-administer during $6 \mathrm{~h} /$ session, and are subsequently more likely to develop patterns of drug taking relevant to addiction (Ahmed, 2012). This work has shown that under limited cocaine access ( $1 \mathrm{~h} /$ session), the speed of intravenous cocaine delivery $(5,45$ or $90 \mathrm{~s})$ does not influence the reinforcing properties of the drug (Wakabayashi et al, 2010). When access to cocaine is extended to $6 \mathrm{~h}$, however, faster cocaine injections lead to greater drug intake and a more persistent vulnerability to drug-primed reinstatement of cocaine-seeking behavior (Wakabayashi et al, 2010).

It has been proposed that regardless of whether rapid delivery might or might not make drugs more reinforcing, rapid delivery increases the potential for addiction because it facilitates the brain changes that promote excessive motivation for drugs (Liu et al, 2005; Samaha et al, 2002; Samaha and Robinson, 2005; Wakabayashi et al, 2010). Repeated drug use can trigger the development of pathological motivation for drug, leading to a state where drugs become progressively harder to resist, and are compulsively pursued in the face of rising costs (Kalivas and Volkow, 2005; Robinson and Berridge, 1993). This progressive increase in the time and effort spent to obtain drugs is a hallmark of drug addiction (DSM-IV). This important aspect of the addiction process was not addressed in Wakabayashi et al (2010). It has been shown previously that breakpoints maintained by cocaine under a progressive ratio (PR) schedule more readily sensitize over time with rapid drug delivery (Liu et al, 2005). However, animals were tested following particularly limited cocaine exposure, and it is increasingly recognized that animal models of addiction must include extended periods of drug taking (Ahmed and Koob, 1998; Belin et al, 2009; Deroche-Gamonet et al, 2004; Vanderschuren and Everitt, 2004).

Here we determined how a history of extended access to rapidly delivered cocaine alters the motivation for the drug. To begin to examine potential neurobiological mechanisms, we quantified the effects of the speed of cocaine delivery on D2 receptor number and function. Reduced striatal D2 receptor availability (Martinez et al, 2004; Volkow et al, 1990) and increased D2 receptor function (Self et al, 1996; Ujike et al, 1990) have each been implicated in the susceptibility to cocaine addiction. Work with nicotine also shows that D2 receptors differentially regulate the SA of rapid $v s$ slower drug injections (Sorge and Clarke, 2009).

\section{MATERIALS AND METHODS}

\section{Animals}

One hundred and ten male Wistar rats (225-250 g; Charles River Laboratories, St Constant, QC) were housed indivi- dually in a climate-controlled colony room maintained on a reverse $12 \mathrm{~h} / 12 \mathrm{~h}$ light/dark cycle (lights off at 0800 hours) Experiments were conducted during the dark phase of the rats' circadian cycle. Food and water were available ad libitum unless noted otherwise. The animal care committee of the Université de Montréal approved all procedures. Sixty-eight animals completed the study. Attrition was due to loss of catheter patency (21 rats), failure to meet criteria for stable cocaine SA behavior (9 rats), ill heath (5 rats), death during surgery (3 rats), cocaine overdose due to experimental error (3 rats), and exclusion due to abnormally aggressive behavior (1 rat).

\section{Drugs}

Cocaine hydrochloride (Medisca Pharmaceutique, St Laurent, QC) was dissolved in saline and filtered with $25-\mathrm{mm}$ Acrodisc syringe filters $(0.2 \mu \mathrm{m}$ GHP membrane; VWR, Town of Mount-Royal, QC).

\section{Apparatus}

Rats were trained and tested in standard operant chambers (Med Associates, St Albans, VT), as described in Samaha et al (2011). Operant chambers were located in a testing room separate from the animals' housing room. 3.33-RPM syringe pump motors delivered cocaine $(0.5$ or $0.25 \mathrm{mg} / \mathrm{kg} /$ infusion) over $5 \mathrm{~s}$ at a rate of $29.23 \mu \mathrm{l} / \mathrm{s}$, and 0.1 -RPM motors delivered 90 -s infusions $(0.85 \mu \mathrm{l} / \mathrm{s})$. A computer running Med Associates Med-PC version IV software controlled the chambers and collected data.

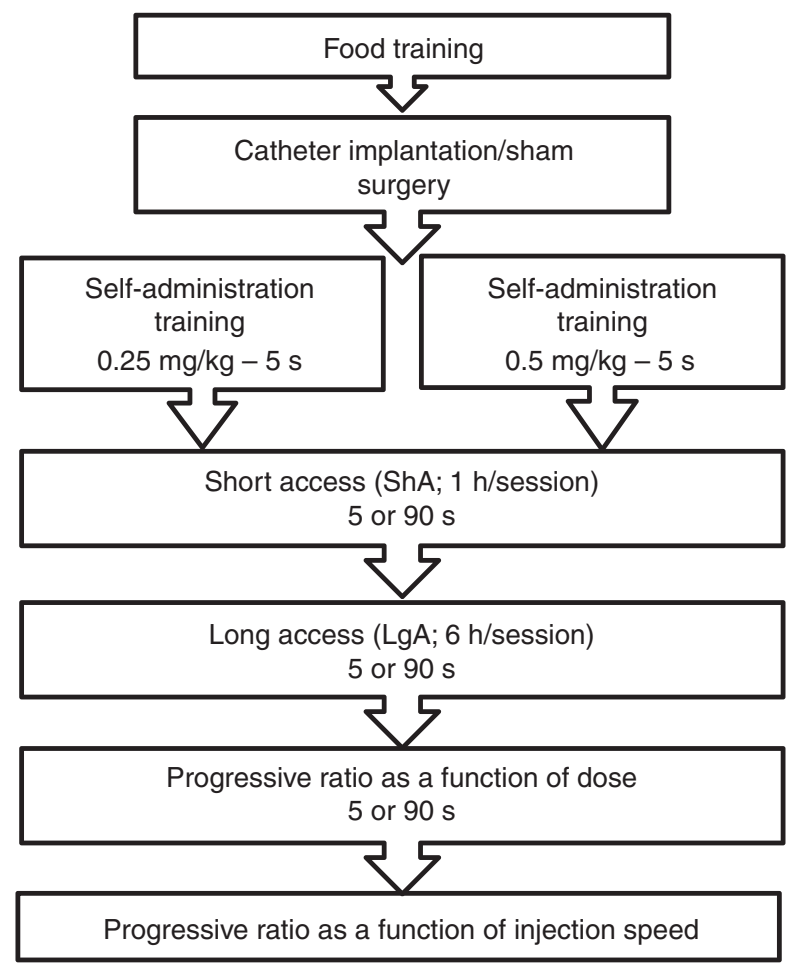

Figure I Timeline of behavioral training and self-administration testing. 


\section{Operant Food Training}

Figure 1 illustrates the experimental events. Rats were trained to lever-press for 45-mg, banana-flavored pellets (grain-based; Cedarlane Laboratories, Burlington, ON) on a continuous reinforcement schedule (fixed ratio 1; FR1). Sessions began with illumination of the house light and insertion of the left lever into the cage (right levers were non-retractable). Each press on the left lever produced one pellet. Sessions ended following 100 pellets or $30 \mathrm{~min}$. Following two sessions, animals that had not received $\geqslant 10$ pellets/session were retrained overnight (16 rats). During the food-training phase, animals received two pellets of standard rat chow after testing. Thereafter, rats received 5-7 standard food pellets/day.

\section{Implantation of Jugular Catheters}

Following operant food training, rats were assigned to one of three groups; a control group (to serve as control in the D2 assays), or groups that would be allowed to selfadminister 0.25 or $0.5 \mathrm{mg} / \mathrm{kg} /$ infusion cocaine. Catheters were constructed and implanted into the jugular vein of rats in the self-administration groups, as in Samaha et al (2011). Control rats underwent sham surgery (incisions and suturing). Thereafter, catheters were flushed on alternate days with either $0.1 \mathrm{ml}$ physiological saline or a solution containing $0.2 \mathrm{mg} / \mathrm{ml}$ Heparin (Sigma-Aldrich, Oakville, $\mathrm{ON}$ ) and $2 \mathrm{mg} / \mathrm{ml}$ Baytril (CDMV, St Hyacinthe, QC). Rats were allowed to recover for 4-10 days before testing. Catheter patency was verified on the day before PR testing by intravenous injection of $0.2 \mathrm{ml}$ of a sodium thiopental solution $(20 \mathrm{mg} / \mathrm{ml}$ in sterile water; Vétoquinol, Lavaltrie, QC). Rats that failed to become ataxic within $5 \mathrm{~s}$ were excluded from the data analysis.

\section{Self-administration Training}

Rats in the two self-administration groups could selfadminister 0.25 or $0.5 \mathrm{mg} / \mathrm{kg} /$ infusion cocaine injected over $5 \mathrm{~s}$ in daily, 1-h sessions under FR1. Sessions began with illumination of the house light and insertion of the left lever. Pressing on the left (active) lever activated the infusion pump and illuminated the cue light above the lever, signalling a 20-s timeout. Pressing on the right (inactive) lever had no programmed consequences.

Self-administration training parameters were adapted from Wakabayashi et al (2010) and consisted of FR1 with a 20-s timeout, then FR2 with the timeout increasing across sessions to 45,65 , and $85 \mathrm{~s}$. We ultimately wished to compare rats self-administering cocaine delivered over 5 or 90 s. An 85-s timeout in the 5-s condition allowed all groups to take one injection every $90 \mathrm{~s}$. Criteria to progress across training steps were $\geqslant 2$ injections/session and twice as many active $v s$ inactive lever presses, for two consecutive sessions.

Starting here in the experiment, control rats were transported to the experimental room and placed in Plexiglas cages for 1-6h/session, for an average of 30 days. Thus, control animals were subjected to similar operant food training, surgical, handling, and transportation procedures, as well as being exposed to novel test cages for sessions that were comparable in number and duration to the self-administration sessions experienced in parallel by animals self-administering cocaine.

\section{Self-administration During Short Access (ShA) Sessions}

Following training, four groups were formed such that the mean number of infusions over the last two training days was equivalent across groups. For three 1-h daily sessions, the groups self-administered 0.25 or $0.5 \mathrm{mg} / \mathrm{kg} /$ infusion cocaine, delivered either over $5 \mathrm{~s}$ with an 85-s timeout or over $90 \mathrm{~s}$ with no timeout, under FR2. Thus, the groups were: $0.25 \mathrm{mg}-5 \mathrm{~s}, 0.25 \mathrm{mg}-90 \mathrm{~s}, 0.5 \mathrm{mg}-5 \mathrm{~s}$, and $0.5 \mathrm{mg}-90 \mathrm{~s}$. In the 5-s groups, the cue light above the lever was illuminated during each 5-s infusion and remained illuminated during the 85-s timeout. In the 90-s condition, the cue light was illuminated during each 90-s infusion. As such, regardless of condition, each cue presentation lasted for $90 \mathrm{~s}$.

\section{Self-administration During Long Access ( $\operatorname{LgA})$ Sessions}

Next, rats could self-administer cocaine as during the ShA phase, except that sessions now lasted $6 \mathrm{~h}$, for a total of 12 sessions. Animals then remained in their home cages for 4-5 days before PR testing.

\section{The Motivation for Cocaine}

Self-administration under $P R$ as a function of dose. Animals self-administered cocaine under PR, where response requirements increased according to the following formula $\left(5 \mathrm{e}^{\text {(injection number } \times 0.2)}\right)-5$, yielding the following ratio progression $1,2,4,6,9,12,15,20,25,32,40,50,62$, etc. (Richardson and Roberts, 1996). For the $0.25-\mathrm{mg} / \mathrm{kg}$ groups, doses of $0.25,0.125$, and $0.063 \mathrm{mg} / \mathrm{kg}$ were tested (2 sessions/dose). For the $0.5-\mathrm{mg} / \mathrm{kg}$ groups, doses of 0.5 , 0.25 , and $0.125 \mathrm{mg} / \mathrm{kg}$ were tested. Doses were given in descending order. Cocaine was injected over $5 \mathrm{~s}$ for the 5 -s groups and over $90 \mathrm{~s}$ for the $90-\mathrm{s}$ groups. Sessions ended when $1 \mathrm{~h}$ elapsed since the last infusion or after $5 \mathrm{~h}$.

Self-administration under $P R$ as a function of speed. During the preceding PR sessions, any group differences in self-administration behavior could be due either to variations in the speed of cocaine delivery in the past (during ShA and $\operatorname{LgA}$ sessions) or variations in the speed of delivery during PR testing. To dissociate these two influences, all the groups were given additional PR sessions during which cocaine was delivered over 5 and 90 s (2-3 sessions/speed). These additional PR tests were given immediately following the preceding dose-response sessions.

\section{D2 Receptor Number and Function}

Fourteen days after the last PR session, 6-7 rats from the $0.25 \mathrm{mg}-5 \mathrm{~s}$ and $0.25 \mathrm{mg}-90 \mathrm{~s}$ groups and the 9 control rats were killed. All brains were extracted, plunged into isopentane $\left(-50{ }^{\circ} \mathrm{C}\right)$, and stored at $-80{ }^{\circ} \mathrm{C}$ until processing. Coronal brain sections $(12 \mu \mathrm{m})$ were cut on a cryostat and mounted onto Snowcoat X-tra slides (Surgipath, Winnipeg, MA, Canada). 
$\left[{ }^{125}\right.$ I] iodosulpiride binding. D2 receptor autoradiography was adapted from Maheux et al (2012). Brain sections were pre-incubated $(15 \mathrm{~min})$ in a $50 \mathrm{mM}$ Tris- $\mathrm{HCl}$ buffer $(\mathrm{pH} 7.4)$ containing $120 \mathrm{mM} \mathrm{NaCl}, 5 \mathrm{mM} \mathrm{KCl}, 1 \mathrm{mM} \mathrm{CaCl} 2,1 \mathrm{mM}$ $\mathrm{MgCl}_{2}, 5.7 \mathrm{mM}$ ascorbic acid, and $10 \mathrm{mM}$ hydroxyquinoline. Slides were then incubated $(1 \mathrm{~h})$ in the same buffer containing $0.2 \mathrm{nM} \quad\left[{ }^{125} \mathrm{I}\right]$ iodosulpride (specific activity $2200 \mathrm{Ci} / \mathrm{mmol}$; PerkinElmer, Woodbridge, ON, Canada). Non-specific binding was evaluated in the presence of $2 \mu \mathrm{M}$ raclopride. Slides were then washed $(2 \times 5 \mathrm{~min})$ in ice-cold Tris- $\mathrm{HCl}$ buffer. Sections were dipped for $10 \mathrm{~s}$ in cold water, dried, and apposed to BioMaxMR film (Kodak, New Haven, $\mathrm{CT}$ ). Autoradiograms were generated after $24 \mathrm{~h}$ of film exposure.

Quinpirole-stimulated $\left[{ }^{35}\right.$ S $]$ GTP $\gamma S$ binding. Agonist-stimulated ${ }^{35}$ S $]$ guanylyl-5'-O-( $\gamma$-thio)-triphosphate ( $\left.\left[{ }^{35} \mathrm{~S}\right] \mathrm{GTP} \gamma \mathrm{S}\right)$ binding autoradiography was adapted from Sim et al (1995) and Sovago et al (2005). Slides were pre-incubated (30 min) in buffer containing $50 \mathrm{mM}$ HEPES (pH 7.4), $5 \mathrm{mM} \mathrm{MgCl}_{2}$, $0.2 \mathrm{mM}$ EGTA, $150 \mathrm{mM} \mathrm{NaCl}, 75 \mathrm{mM} \mathrm{KCl} 1 \mathrm{mM}$ DLdithiothreitol, and $2 \mathrm{mM}$ guanosine $5^{\prime}$-diphosphate (GDP; Sigma-Aldrich, St Louis, MO) at $37^{\circ} \mathrm{C}$. Basal and agoniststimulated activities were determined by incubating the slides with $0.05 \mathrm{nM}\left[{ }^{35} \mathrm{~S}\right] \mathrm{GTP} \gamma \mathrm{S}$ (specific activity, $1250 \mathrm{Ci} / \mathrm{mmol}$; PerkinElmer) with or without the D2 agonist quinpirole $(10 \mu \mathrm{M})$ in the same assay buffer at $37^{\circ} \mathrm{C}$ for $1.5 \mathrm{~h}$. In preliminary experiments, D2 receptor specificity of quinpirole-stimulated $\left[{ }^{35} \mathrm{~S}\right] \mathrm{GTP} \gamma \mathrm{S}$ binding was examined by addition of raclopride $(10 \mu \mathrm{M})$. Non-specific $\left[{ }^{35} \mathrm{~S}\right] \mathrm{GTP} \gamma \mathrm{S}$ binding was assessed in the presence of $10 \mu \mathrm{M}$ unlabeled GTP $\gamma$ S (Sigma-Aldrich, St Louis, MO). Slides were then rinsed $(2 \times 10 \mathrm{~min})$ in ice-cold buffer $(50 \mathrm{mM}$ HEPES, $\mathrm{pH}$ 7.4 at $37^{\circ} \mathrm{C}$ ) and immersed in ice-cold distilled water. Slides were dried overnight and apposed to BioMaxMR film. Autoradiograms were generated after $36 \mathrm{~h}$ of film exposure.

Quantification. An experimenter blind to condition translated optical densities from autoradiograms into $\mu \mathrm{Ci} / \mathrm{g}$ of tissue using $\left[{ }^{14} \mathrm{C}\right]$ radioactivity standards (ARC $146 \mathrm{~A}-{ }^{14} \mathrm{C}$; American Radiolabeled Chemicals, St Louis, MO) and ImageJ software (NIH, Bethesda, MD). Agoniststimulated $\left[{ }^{35} \mathrm{~S}\right] \mathrm{GTP} \gamma \mathrm{S}$ activity (net stimulation) was calculated for each rat by subtracting the optical density in basal brain sections (incubated with GDP alone) from that in quinpirole-stimulated sections. Results are expressed as percentage of change from net stimulation in controls. Optical densities were quantified in caudate-putamen quadrants (1.6, 1.2, 0.8, and $0.4 \mathrm{~mm}$ from Bregma, 1 section/level), the nucleus accumbens $(2.0,1.6,1.2$, and $0.8 \mathrm{~mm}$ ), and prelimbic, infralimbic (both at $2.6 \mathrm{~mm}$ ), and orbitofrontal $(3.0 \mathrm{~mm})$ cortices, according to Paxinos and Watson, (1986). For the $\left[{ }^{35} \mathrm{~S}\right] \mathrm{GTP} \gamma \mathrm{S}$ binding assay, we also quantified optical densities in the frontal and parietal cortices (both at 1.6 and $0.8 \mathrm{~mm}$ ).

\section{Statistics}

Behavioral data during ShA and LgA sessions were analyzed using one-way and two-way (group $\times 2$-session block) ANOVA, respectively. Infusions under PR were analyzed using two-way ANOVA (group $\times$ PR dose or PR speed). Significant interaction effects under PR were investigated with two-tailed unpaired $t$-tests. D2 data were analyzed using two-way ANOVA (group $\times$ rostro-caudal level) except in regions where only one rostro-caudal level was analyzed (orbitofrontal and prefrontal cortices), in which case oneway ANOVA was used.

\section{RESULTS}

\section{Self-administration During ShA Sessions}

Figure 2 illustrates SA behavior averaged over the last two of the three ShA sessions. Cocaine delivery speed had no effect on the average number of cocaine infusions (a) or interinfusion interval ((b); all $P$ 's $>0.05)$.

\section{Self-administration During LgA Sessions}

Figure 3 shows self-administration behavior during $\operatorname{LgA}$ sessions. The ShA sessions shown in Figure 2 are also included in Figure 3a-f for comparison. When sessions were extended from 1 (ShA) to $6 \mathrm{~h}$ (Figure $3 \mathrm{~b}$ and d), all the groups increased their total drug intake (ShA vs first 2session block; main effect of session; (b) $F(1,22)=71.76$; (d): $\mathrm{F}(1,30)=146.94$; all $\left.P^{\prime} \mathrm{s}<0.0001\right)$. However, despite having equal opportunity to self-administer cocaine (ie, all rats could only take one injection every $90 \mathrm{~s}$ ), the 5 -s groups took significantly more drug in the first hour as well as after $6 \mathrm{~h}$ during the LgA sessions (main effect of group; (a) $\mathrm{F}(1,22)=7.55$; (b) $\mathrm{F}(1,22)=11.87$; (c) $\mathrm{F}(1,30)=28.72$; (d) $\mathrm{F}(1,30)=38.41$; all $\left.P^{\prime} \mathrm{s}<0.02\right)$.

Figure $3 \mathrm{e}$ and $\mathrm{f}$ show the inter-infusion interval as a function of group. During LgA sessions, the 90-s rats waited longer between each self-administered infusion as compared with the 5-s rats (main effect of group; (e) $\mathrm{F}(1,22)$ $=5.67, P=0.03$; (f) $\mathrm{F}(1,30)=6.40, P=0.02$ ). Inspection of Figure $3 \mathrm{e}$ and $\mathrm{f}$ also reveals that the self-imposed interinfusion interval in the 5-s rats was considerably longer than the experimenter-imposed 90 -s timeout interval in these groups. This suggests that the 90 -s timeout in the 5 -s groups did not artificially constrain self-administration behavior.

As shown in Figure $3 \mathrm{~g}$, cumulative drug intake was greatest in the $0.5 \mathrm{mg} / \mathrm{kg}$-5-s group (main effect of group; vs $0.5 \mathrm{mg} / \mathrm{kg}-90-\mathrm{s}, \mathrm{F}(1,30)=30.08 ;$ vs $0.25 \mathrm{mg} / \mathrm{kg}-5$-s, $\mathrm{F}(1,27)=$ $22.48 ; \quad v s \quad 0.25 \mathrm{mg} / \mathrm{kg}-90-\mathrm{s}, \mathrm{F}(1,25)=61$; all $P$ 's $<0.0001)$. Also, at the $0.25 \mathrm{mg} / \mathrm{kg}$ dose, the 5-s group took more cocaine than the 90 -s group $(\mathrm{F}(1,22)=12.23, P=0.002)$. No other comparisons were significant.

Inactive lever presses, unreinforced active lever presses, and within-session variability in the inter-infusion interval are illustrated in Supplementary Figure S1. Unreinforced active lever presses were defined as active lever presses made either during the 5-s infusion and 85-s timeout period (5-s groups) or during the 90-s infusion (90-s groups). Within-session variability in the inter-infusion interval was calculated using the root mean square of successive differences (rMSSD). During LgA sessions, the speed of cocaine delivery did not influence inactive lever presses (main effect of group; (a) $\mathrm{F}(1,22)=2.37$; (b) $\mathrm{F}(1,30)=1.73$; All $P$ 's $>0.05)$ or unreinforced active lever presses ((c) $\mathrm{F}(1,22)=1.04 ;$ (d) $\mathrm{F}(1,30)=1.41$; All $\left.P^{\prime} \mathrm{s}>0.05\right)$. In animals 
a

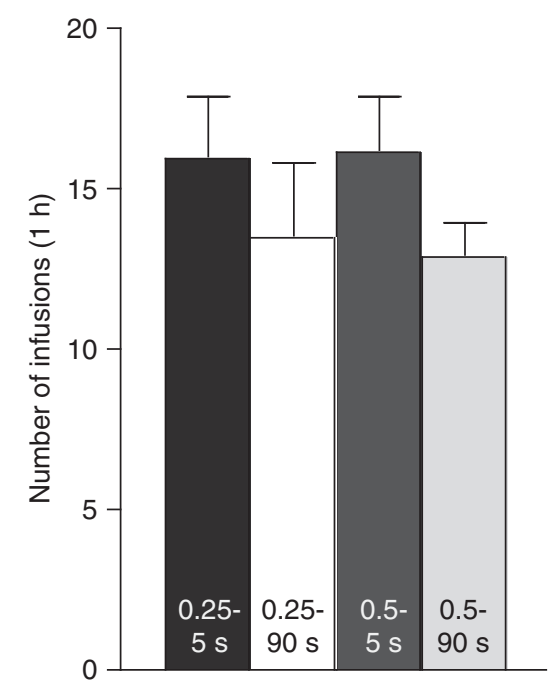

b

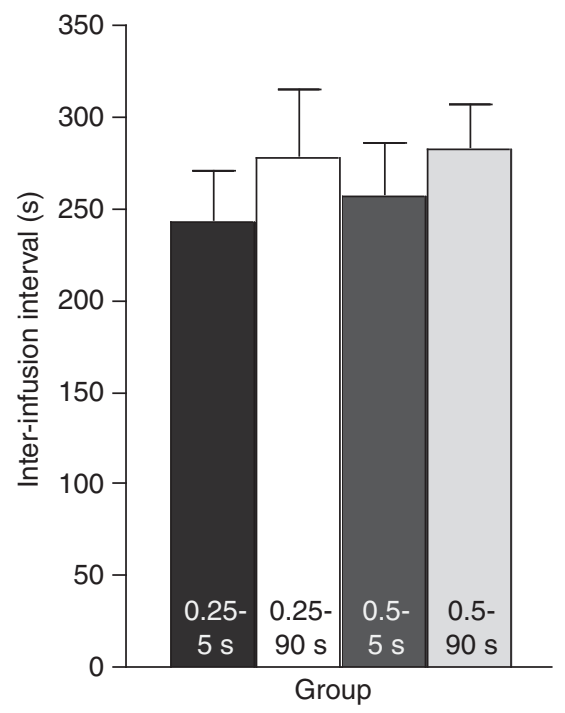

C

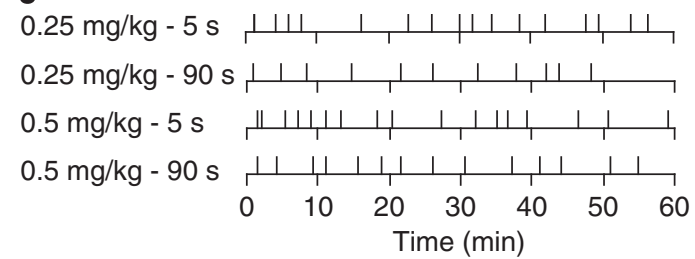

Figure 2 The speed of intravenous cocaine delivery does not influence self-administration behavior when access to the drug is limited (I h/session). Number of infusions earned (a) and inter-infusion interval (b) in animals self-administering 0.5 or $0.25 \mathrm{mg} / \mathrm{kg} /$ infusion cocaine delivered over 5 or $90 \mathrm{~s}$. (c) Cumulative response records for self-administered infusions in a representative rat from each group during the last of the three ShA sessions. Data represent mean \pm SEM. $n=||-\mid 6 /$ group.

self-administering $0.25 \mathrm{mg} / \mathrm{kg} /$ infusion cocaine, $\mathrm{rMSSD}$ over the $12 \mathrm{LgA}$ sessions was greater in the $90-v s$ the 5 -s group (main effect of group; (e) $\mathrm{F}(1,22)=8.01 ; P<0.01$ ). There was a tendency towards a similar effect in animals self-administering $0.5 \mathrm{mg} / \mathrm{kg} /$ infusion cocaine ((f) $\mathrm{F}(1,30)=4.12, P=0.0513)$. Thus, animals self-administering slower cocaine injections (delivered over 90 vs $5 \mathrm{~s}$ ) evidence a more irregular pattern of SA during each LgA session.

\section{The Motivation for Cocaine}

Figure 4 shows cocaine intake under a PR schedule of reinforcement. As during the previous FR self-administration sessions, all rats could only take one injection every $90 \mathrm{~s}$ during the PR tests. In Figure $4 \mathrm{a}$ and $\mathrm{b}$, cocaine was delivered over $5 \mathrm{~s}$ for the 5 -s groups and over $90 \mathrm{~s}$ for the 90-s groups. Across all cocaine doses tested, animals in the 5-s groups self-administered more drug than animals in the 90-s groups (main effect of group; (a) $\mathrm{F}(1,22)=26.72$, (b) $\mathrm{F}(1,30)=16.40$; all $P$ 's $<0.0004)$. Also, there were qualitative differences in self-administration behavior under PR. Animals in the 5-s groups increased their drug intake with increasing dose (group $\times$ dose interaction effect; (b) $\mathrm{F}(2,60)=7.52, P=0.001$; and a similar tendency in (a), $\mathrm{F}(2,44)=2.92, P=0.06)$. In contrast, animals in the 90 -s groups took comparable amounts of cocaine at all of the doses tested (Figure $4 \mathrm{a}$ and $\mathrm{b}$; all $P$ 's $>0.05$ ).

Figure $4 \mathrm{c}$ and $\mathrm{d}$ show the effects of delivering cocaine over 5 or 90 s during PR testing in rats that had previously selfadministered cocaine delivered over 5 or $90 \mathrm{~s}$. Thus, during these PR tests, the speed of drug delivery was the same for all rats. In Figure $4 c$, there was a significant main effect of group $(\mathrm{F}(1,22)=4.90, P=0.04)$ and a significant group $\times$ $\mathrm{PR}$ speed interaction effect $(\mathrm{F}(1,22)=4.97, P=0.04)$. Investigation of this interaction revealed that when cocaine was delivered over $90 \mathrm{~s}$ during PR testing, rats that had previously self-administered 5-s cocaine infusions took more drug than rats that had previously self-administered 90-s cocaine infusions $(t(22)=3.17, P=0.004)$. In Figure $4 \mathrm{~d}$, rats that had previously self-administered cocaine delivered over $5 \mathrm{~s}$ took more drug than their 90-s counterparts, regardless of whether cocaine was delivered over 5 or $90 \mathrm{~s}$ during PR testing (main effect of group; $\mathrm{F}(1,30)=6.26, P=0.018)$.

\section{D2 Receptor Number and Function}

There were no group differences in $\mathrm{D} 2$ receptor density in the nucleus accumbens (Figure 5; two-way ANOVA; main effect of group; (e), $\mathrm{F}(2,18)=0.20$; (f), $\mathrm{F}(2,18)=0.05$; all $P$ 's $>0.05$ ) or in any of the cortical areas quantified (data not shown; all $P$ 's $>0.05$ ). As shown in Figure 5, the speed of cocaine delivery altered D2 receptor density in the caudateputamen (two-way ANOVA on levels $1.2-0.4 \mathrm{~mm}$ relative to Bregma; main effect of group; $\mathrm{DM}, \mathrm{F}(2,19)=4.18$; DL, $\mathrm{F}(2,19)=7.76 ; \mathrm{VL}, \mathrm{F}(2,19)=5.02$; all $P$ 's $<0.05$; with the exception of the VM, $P=0.11)$. D2 receptor density was decreased in the 90-s group as compared with either the control or the 5-s group (DM, $90 \mathrm{~s}$ vs Control, $\mathrm{F}(1,14)=7.91,90$ vs $5 \mathrm{~s}, \mathrm{~F}(1,11)=8.02 ; \mathrm{DL}, 90 \mathrm{~s}$ vs Control, $\mathrm{F}(1,14)=14.52,90 \quad v s \quad 5 \mathrm{~s}, \mathrm{~F}(1,11)=13.68 ; \mathrm{VL}, 90 \mathrm{~s}$ vs Control, $\mathrm{F}(1,14)=8.93,90$ vs $5 \mathrm{~s}, \mathrm{~F}(1,11)=8.60 ; \mathrm{VM}, 90 \mathrm{~s}$ vs Control, $\mathrm{F}(1,14)=5.49$; but not vs $5 \mathrm{~s}, \mathrm{~F}(1,11)=3.28$, $P=0.10$; all other $P$ 's $<0.05)$. There were no significant differences in D2 receptor levels between the 5-s and the control groups (all $P^{\prime}$ s $>0.05$ ).

With regard to D2 receptor function, there were group differences in the basal levels of $\left[{ }^{35} \mathrm{~S}\right] \mathrm{GTP} \gamma \mathrm{S}$ binding (data not shown; two-way ANOVA on 1.6-0.4 mm; DM, $\mathrm{F}(2,19)=6.12 ; \mathrm{DL}, \mathrm{F}(2,18)=4.89 ; \mathrm{VM}, \mathrm{F}(2,19)=7.68 ; \mathrm{VL}$, $\mathrm{F}(2,19)=7.11$; all $P$ 's $<0.02)$. Relative to both the 5-s and 


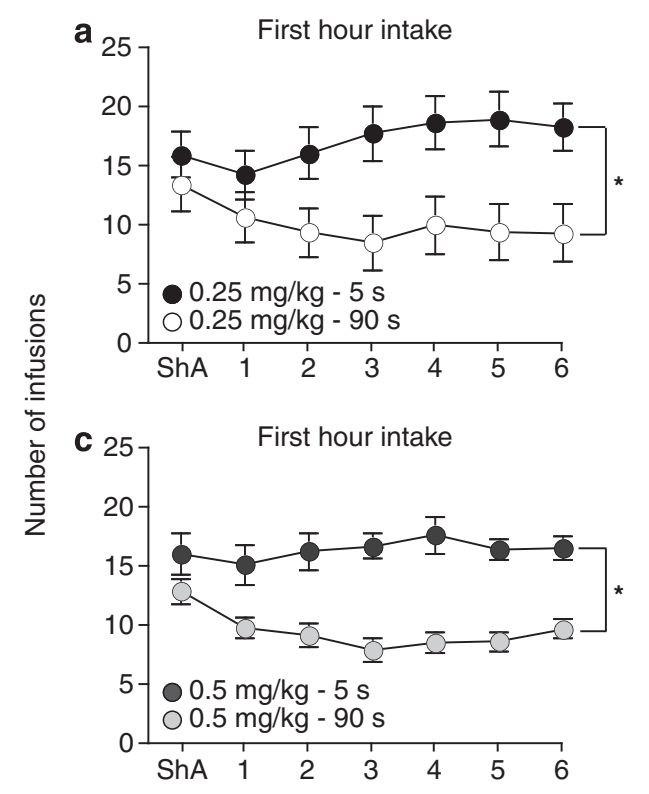

b $\quad 150 \quad$ Total intake $(6 \mathrm{~h})$

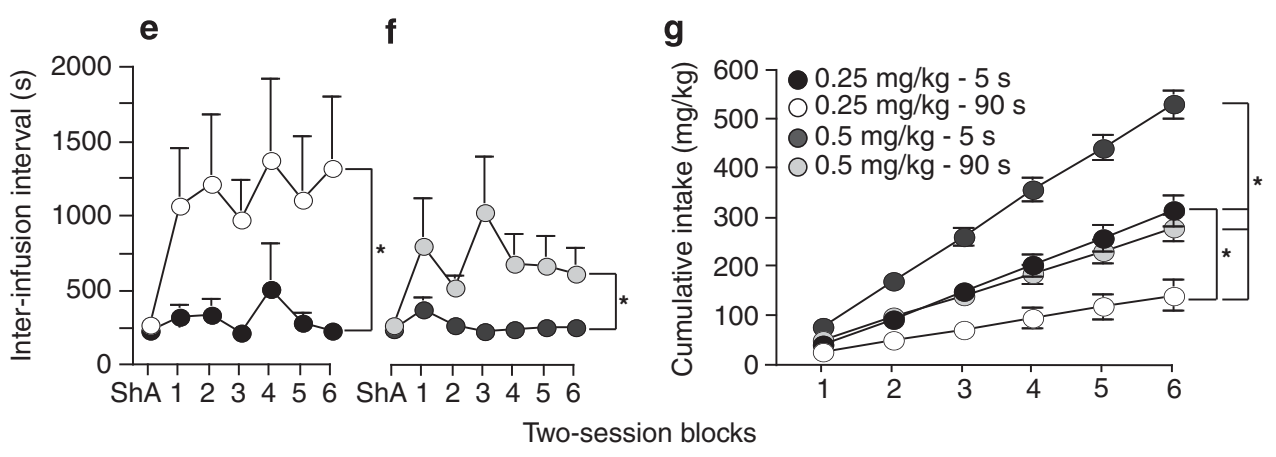

Figure 3 When access to cocaine is extended to $6 \mathrm{~h}$ per session, rats self-administering rapid cocaine injections (delivered over 5 vs $90 \mathrm{~s}$ ) take more drug. Number of infusions earned during the first hour of the 6-h sessions ( $a, c)$ or during the entire $6-\mathrm{h}$ session (b, d) by rats self-administrating 0.25 or $0.5 \mathrm{mg} / \mathrm{kg} /$ infusion cocaine delivered over 5 or $90 \mathrm{~s}$. The inter-infusion interval in rats self-administering 0.25 (e) or $0.5 \mathrm{mg} / \mathrm{kg} /$ infusion cocaine (f) delivered over 5 or $90 \mathrm{~s}$. (g) Cumulative cocaine intake over the 12 6-h sessions as a function of group. The number of infusions averaged over the last two ShA sessions is included for comparison in all of the panels except for panel g. All values are mean \pm SEM. $n=1 \mid-16 /$ group. ShA, short access. $* P<0.05$.

control groups, the 90-s group had lower basal levels of $\left[{ }^{35} \mathrm{~S}\right] \mathrm{GTP} \gamma \mathrm{S}$ binding in the caudate-putamen (main effect of group; DM, $90 \mathrm{~s}$ vs Control, $\mathrm{F}(1,14)=10.27,90$ vs $5 \mathrm{~s}$, $\mathrm{F}(1,11)=13.9 ; \mathrm{DL}, 90 \mathrm{~s}$ vs Control, $\mathrm{F}(1,14)=8.07,90$ vs $5 \mathrm{~s}$, $\mathrm{F}(1,10)=17.39 ; \mathrm{VM}, 90 \mathrm{~s}$ vs Control, $\mathrm{F}(1,14)=13.94,90$ vs $5 \mathrm{~s}, \mathrm{~F}(1,11)=8.94$; VL, $90 \mathrm{~s} v \mathrm{~s}$ Control, $\mathrm{F}(1,14)=12.59,90 v \mathrm{~s}$ $5 \mathrm{~s}, \mathrm{~F}(1,11)=11.21$; all $P$ 's $<0.02)$. Basal $\left[{ }^{35} \mathrm{~S}\right] \mathrm{GTP} \gamma \mathrm{S}$ activity in the caudate-putamen was comparable between the 5-s and the control groups (all P's $>0.05$ ).

In addition, there were significant group differences in agonist-stimulated $\left[{ }^{35}\right.$ S $]$ GTP $\gamma$ S activity in the caudate-putamen (Figure 6 illustrates these data as the percentage of change from net stimulation in control animals; overall two-way ANOVA on 1.2-0.8 mm; DM, F $(2,19)=9.00 ; \mathrm{DL}$, $\mathrm{F}(2,19)=9.60 ; \mathrm{VM}, \mathrm{F}(2,19)=11.52$; $\mathrm{VL}(2,19)=11.74$; all $P$ 's $<0.002$ ). Relative to controls, the 5-s group had greater levels of quinpirole-stimulated $\left[{ }^{35} \mathrm{~S}\right] \mathrm{GTP} \gamma \mathrm{S}$ activity in ventral aspects of the caudate-putamen (main effect of group; VM, $\mathrm{F}(1,13)=6.57$; VL, $\mathrm{F}(1,13)=5.97$; all $P$ 's $<0.05$; DM and DL, $P$ 's $>0.05$ ). The 90 -s group was significantly different from controls in all caudate-putamen quadrants $(\mathrm{DM}, \mathrm{F}(1,14)=19.50 ; \mathrm{DL}, \mathrm{F}(1,14)=19.85 ; \mathrm{VM}, \mathrm{F}(1,14)=$
24.39; VL, $\mathrm{F}(1,14)=21.33$; all $P$ 's $<0.05)$. The 90-s group also had greater levels of quinpirole-stimulated $\left[{ }^{35} \mathrm{~S}\right] \mathrm{GTP} \gamma \mathrm{S}$ activity in the caudate-putamen relative to the 5-s group (two-way ANOVA on 1.2-0.8 mm; main effect of group; $\mathrm{DM}, \mathrm{F}(1,11)=6.09 ; \mathrm{DL}, \mathrm{F}(1,11)=6.55 ; \mathrm{VL}, \mathrm{F}(1,11)=5.03$; all $P$ 's $<0.05$; with the exception of VM, $P=0.11$ ). In the nucleus accumbens core and shell (Figure 6e and f), there was no effect of the speed of cocaine delivery (all $P$ 's $>0.05$ ), but both cocaine groups had increased quinpirole-stimulated $\left[{ }^{35} \mathrm{~S}\right] \mathrm{GTP} \gamma \mathrm{S}$ binding relative to control animals (overall two-way ANOVA on 1.6 and $1.2 \mathrm{~mm}$ relative to Bregma; core, $\mathrm{F}(2,15)=6.77$; shell, $\mathrm{F}(2,15)=9.47$; Core, $5 \mathrm{~s} v \mathrm{~s}$ Control, $\mathrm{F}(1,9)=9.83$; $90 \mathrm{~s}$ vs Control, $\mathrm{F}(1,11)=10.09$; Shell, $5 \mathrm{~s} v s$ Control, $\mathrm{F}(1,9)=10.50$; $90 \mathrm{~s}$ vs Control, $\mathrm{F}(1,11)=$ 12.13; All $P$ 's $<0.02)$. There were no group differences in any of the cortical areas quantified (data not shown; all $P$ 's $>0.05$ ).

In summary, the largest effects on D2 receptor number and function were observed in the caudate-putamen. Striatal D2 receptor density was decreased only in animals that had chronically self-administered slow cocaine infusions (delivered over $90 \mathrm{~s}$ ), and D2 agonist-stimulated 

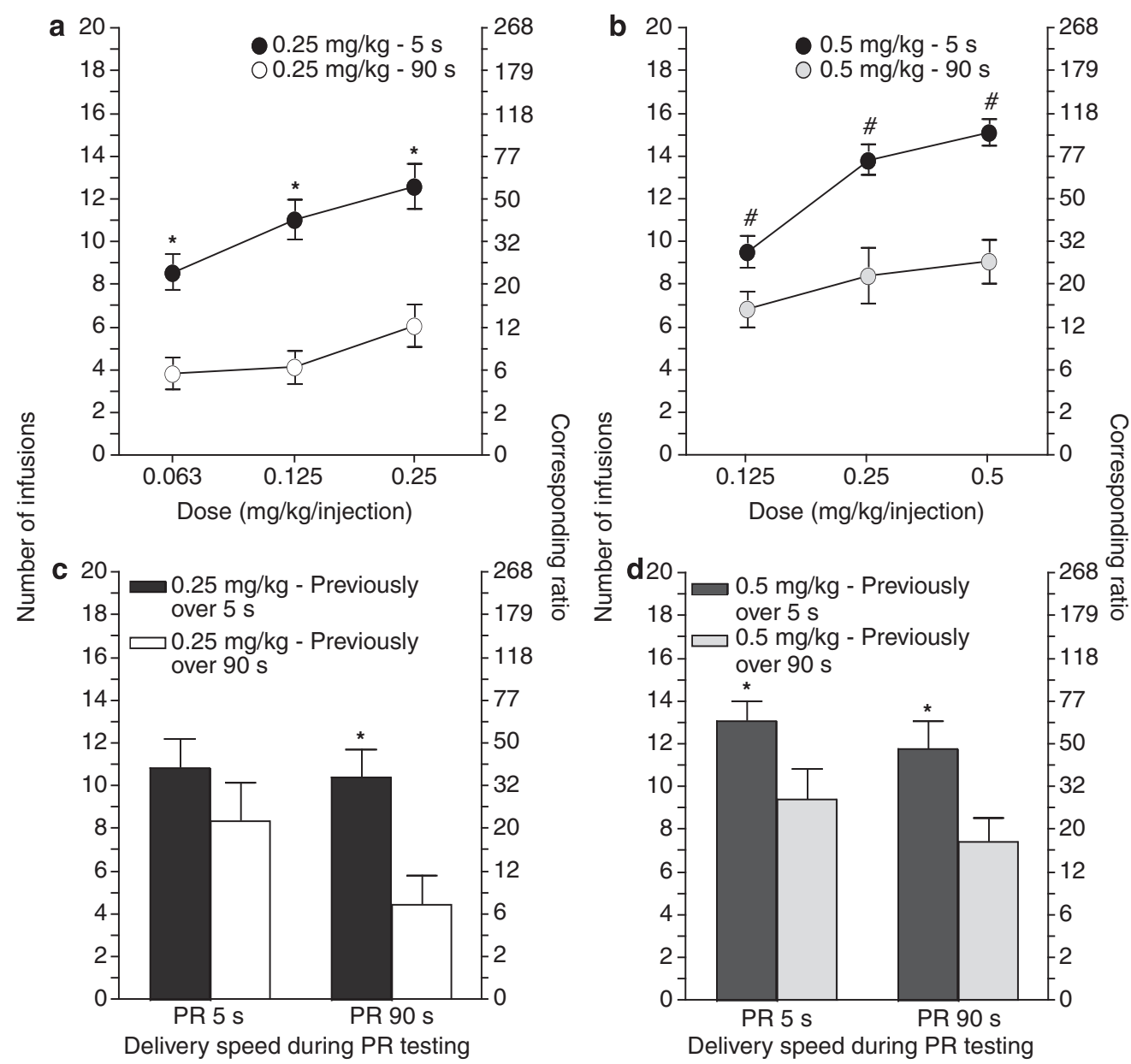

Figure 4 Animals that have self-administered rapid cocaine injections (delivered over 5 vs $90 \mathrm{~s}$ ) are more motivated to obtain the drug. In panels a and b, different doses of cocaine were delivered over $5 \mathrm{~s}$ for the 5 -s groups and over $90 \mathrm{~s}$ for the 90 -s groups, under a progressive ratio schedule. In panels $\mathrm{c}$ and $\mathrm{d}$, cocaine was delivered over 5 and $90 \mathrm{~s}$ during progressive ratio testing in rats that had previously self-administered $0.25 \mathrm{mg} / \mathrm{kg} / \mathrm{infusion}$ or $0.5 \mathrm{mg} / \mathrm{kg} / \mathrm{infusion}$ cocaine delivered over 5 or $90 \mathrm{~s}$. Values are mean \pm SEM of 2-3 sessions/dose or injection speed. $n=11-16 /$ group. PR $5 \mathrm{~s}$, cocaine was delivered over $5 \mathrm{~s}$ during progressive ratio testing. PR $90 \mathrm{~s}$, cocaine was delivered over $90 \mathrm{~s}$ during progressive ratio testing. $*$ P $<0.05$ compared with the 90 -s group. ${ }^{\#} P<0.000$ I compared with the 90 -s group.

$\mathrm{G} \alpha_{\mathrm{i} / \mathrm{o}}$-protein activation was increased to a greater extent in the $90-v s$ 5-s rats.

\section{DISCUSSION}

Our objective here was to determine whether a history of chronic exposure to rapidly delivered cocaine promotes increased motivation to take the drug. Rats first self-administered cocaine delivered intravenously over 5 or $90 \mathrm{~s}$ under a FR schedule of reinforcement during 1- and 6-h sessions. The motivation to self-administer cocaine was then assessed using a PR schedule of reinforcement. The PR procedure measures motivation for drugs by quantifying the maximal amount of operant responding (lever-pressing in our case) that an animal will perform to obtain a single drug infusion before cessation of responding (Richardson and Roberts, 1996). During all self-administration sessions, rats in all of the groups had equal opportunity to take cocaine (one injection was available every $90 \mathrm{~s}$ ). Consistent with previous work, the speed of cocaine delivery influenced self-administration behaviour when access to cocaine was extended to 6 hours/session but not when it was limited to
1 hour/session (Wakabayashi et al, 2010). When given extended access to the drug, animals self-administering rapid cocaine injections (delivered over $5 \mathrm{~s}$ ) took almost twice as more drug than rats self-administering more sustained cocaine injections $(90 \mathrm{~s})$. It has been proposed that limited access procedures are best suited to study acute reinforcement, whereas extended access is a better model to study the progressive changes in the behavioral and brain effects of drugs that characterize the addiction process (Ahmed, 2012; Roberts et al, 2007). If this is true, then it might not be so surprising that varying drug injection speed between 5 and $100 \mathrm{~s}$ does not dramatically alter the acute reinforcing strength of cocaine during limited sessions but determines the susceptibility to increase cocaine intake in a more addiction-relevant, extended access model ((Crombag et al, 2008; Pickens et al, 1969; Wakabayashi et al, 2010) and present findings). Similarly, varying the speed of cocaine delivery over the same range does not alter the acute locomotor response to the drug but does determine the development of psychomotor sensitization to cocaine (Samaha et al, 2002; Samaha et al, 2004). 

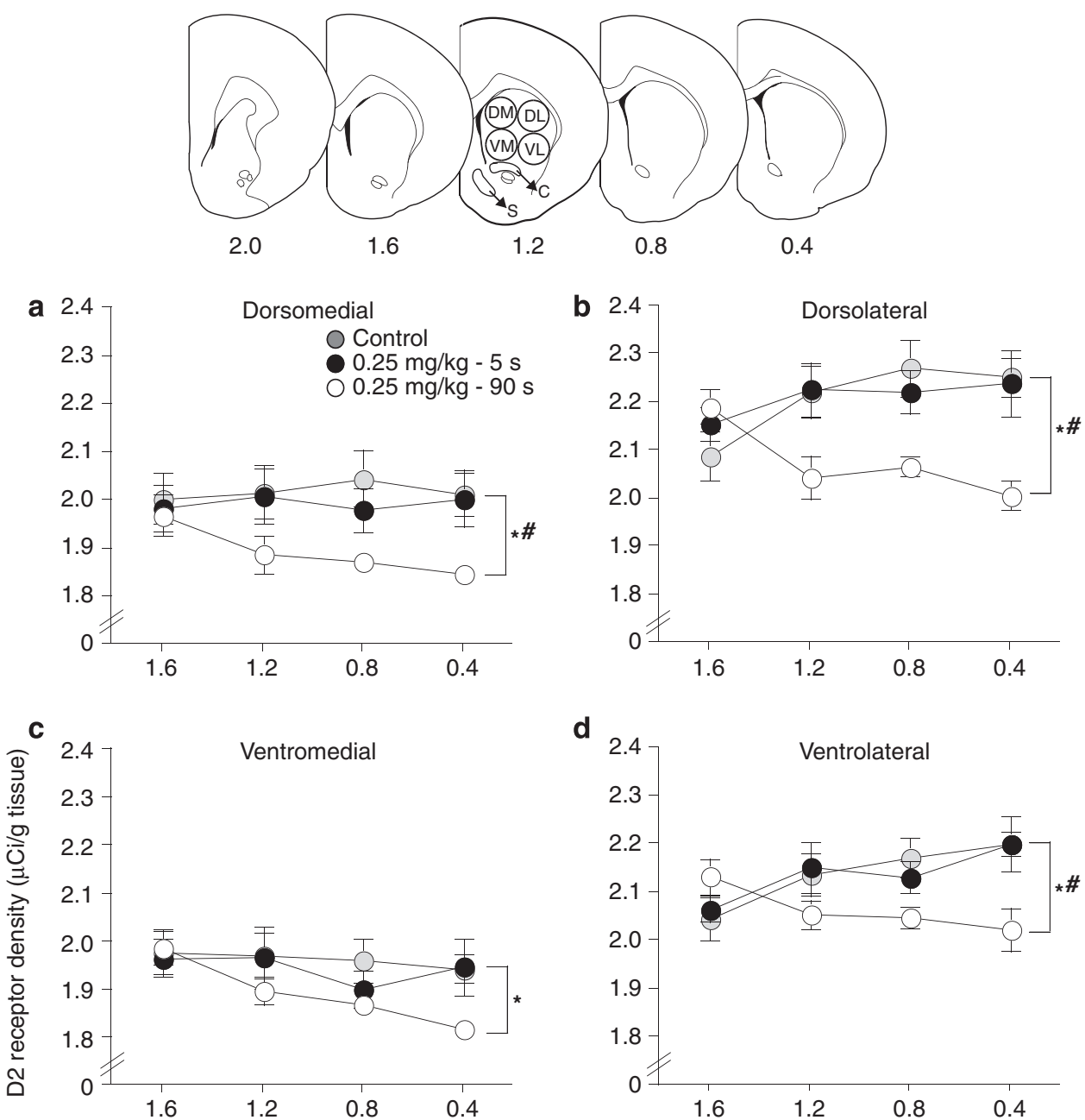

e

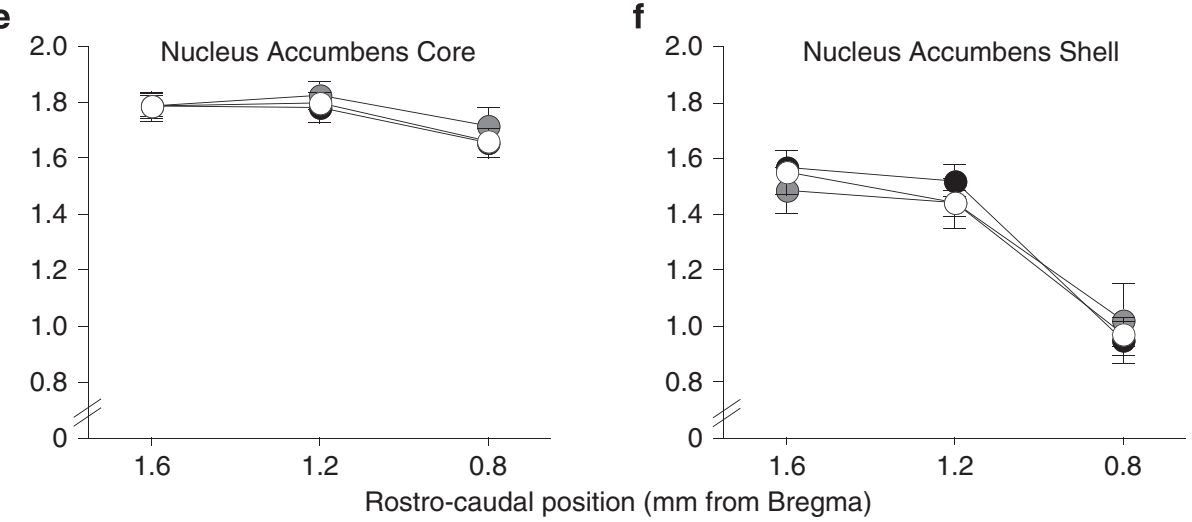

Figure 5 A history of self-administering slow (delivered over $90 \mathrm{~s}$ ) but not rapid cocaine injections ( $5 \mathrm{~s}$ ) decreases D2 receptor density in the caudateputamen. D2 receptor density in the dorsomedial (a), dorsolateral (b), ventromedial (c), and ventrolateral (d) quadrants of the caudate-putamen and in the core (e) and shell $(\mathrm{f})$ of the nucleus accumbens 14 days after the last self-administration session in animals that had self-administered cocaine delivered over 5 or $90 \mathrm{~s}$ and in control rats. Receptor density was measured by autoradiographic binding with $\left({ }^{125} \mathrm{I}\right)$ iodosulpiride. $\mu \mathrm{Ci} / \mathrm{g}$, microcurie per gram of tissue. C, nucleus accumbens core. S, nucleus accumbens shell. Data represent mean \pm SEM. $n=6-9 /$ group. $* P<0.0590$-s group compared with the control group at levels 1.2-0.4. ${ }^{\#} P<0.0590$-s group compared with the 5-s group at levels $1.2-0.4$.

Animals given extended access to cocaine often escalate their intake of drug over time (Ahmed, 2012). However, we observed no such escalation. Studies giving extended access to doses of cocaine similar to the ones used here do not always report escalated drug intake (Ferrario and Robinson,
2007; Kippin et al, 2006; Mantsch et al, 2004). Escalation is also reported to be more likely at higher doses of cocaine ( $2 \mathrm{mg} / \mathrm{kg} /$ infusion; (Mantsch et al, 2004)). Finally, rats can show significant inter-individual variability in the propensity to escalate their drug intake (Deroche-Gamonet et al, 

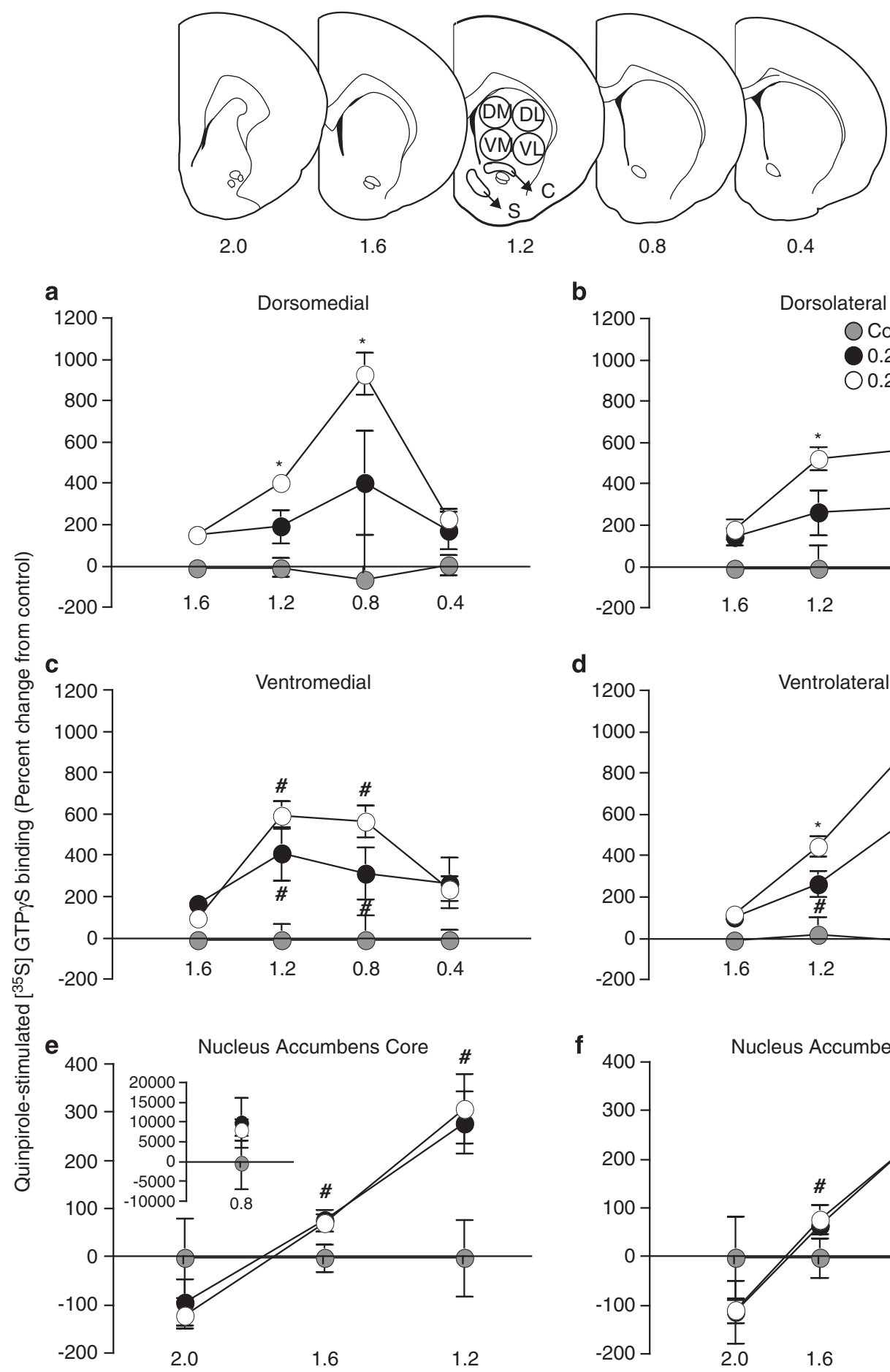

b
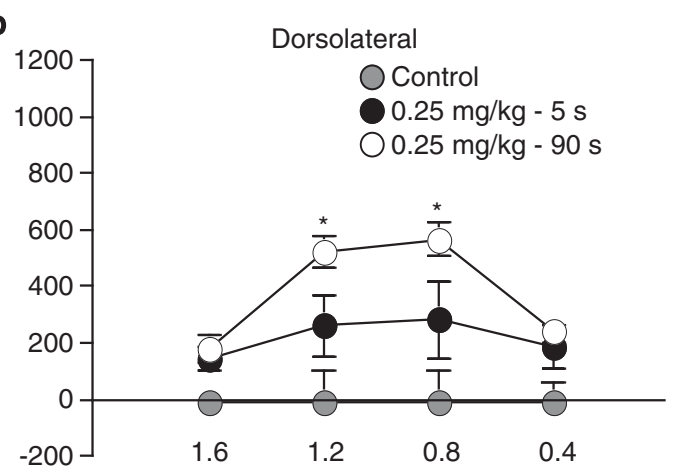

d
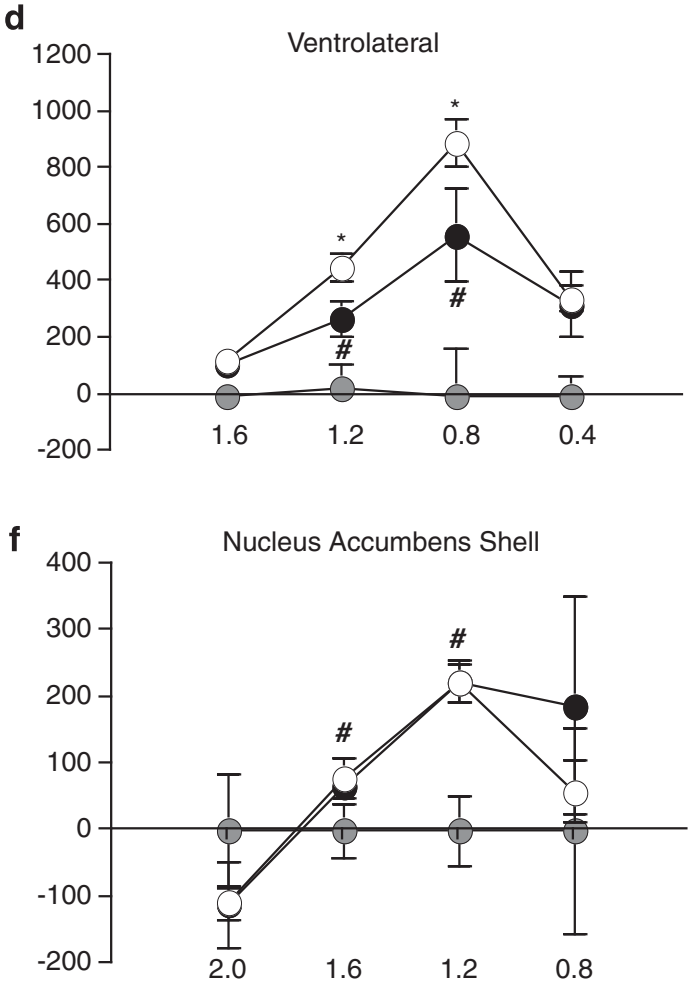

Rostro-caudal position ( $\mathrm{mm}$ from Bregma)

Figure 6 A history of self-administering slow cocaine injections (delivered over 90 vs $5 \mathrm{~s}$ ) leads to a greater increase in agonist-stimulated $\left[{ }^{35} \mathrm{~S}\right] \mathrm{GTP} \gamma \mathrm{S}$ binding in the caudate-putamen. Quinpirole-stimulated $\left.{ }^{35} \mathrm{~S}\right] \mathrm{GTP} \gamma \mathrm{S}$ activity in the dorsomedial (a), dorsolateral (b), ventromedial (c), and ventrolateral (d) quadrants of the caudate-putamen, as well as in the nucleus accumbens core (e) and shell ( $\mathrm{f}$ ) 14 days after the last self-administration session in animals that had self-administered cocaine delivered over 5 or $90 \mathrm{~s}$ and in control rats. In panel (e), the inset shows data at $+0.8 \mathrm{~mm}$ relative to Bregma. C, nucleus accumbens core; S, nucleus accumbens shell. Data represent mean \pm SEM. $n=6-7 / g r o u p . ~ * P<0.05$ relative to the 5-s group at corresponding rostro-caudal position. ${ }^{\#} P<0.05$ relative to the control group at corresponding rostro-caudal position.

2004; Wakabayashi et al, 2010). It is also noteworthy that under FR, the rats self-administering $0.5 \mathrm{mg} / \mathrm{kg} /$ infusion cocaine, regardless of infusion speed, took a similar number of infusions compared with the rats self- administering $0.25 \mathrm{mg} / \mathrm{kg} /$ infusion. The two doses might not have been far enough apart on the dose-response curve to evoke differences in cocaine intake (Mantsch et al, 2001; Wee et al, 2007). 
In addition to influencing cocaine intake, a major finding of the current study is that the speed of cocaine delivery determines the subsequent motivation to obtain the drug. Animals that had self-administered rapid cocaine injections worked significantly harder for the drug under a PR schedule and did so across a range of doses and different speeds of cocaine delivery during PR testing. Varying the rate of cocaine delivery led to both quantitative and qualitative differences in cocaine intake under PR conditions. Animals that had previously self-administered rapid cocaine infusions worked harder to obtain the drug across a range of doses. Also, the 5-s rats showed a dose-dependent decrease in cocaine intake under PR, as rats usually do (Roberts et al, 1989). In contrast, the 90-s rats maintained the same level of drug intake regardless of dose. It is not clear why rats in the 90-s condition were insensitive to variations in cocaine dose. However, in typical SA studies drug is injected in $<10 \mathrm{~s}$. To our knowledge, this is the first published report of a dose-response curve under a PR schedule in animals self-administering slower cocaine injections. Rats that had self-administered rapid cocaine injections in the past (delivered over $5 v s 90 \mathrm{~s}$ ) also worked harder for the drug regardless of whether cocaine was delivered over 5 or $90 \mathrm{~s}$ during PR testing. This suggests that the motivation for cocaine is determined by the speed of self-administered cocaine injections in the past and not simply by the speed of drug delivery during PR testing (see also (Liu et al, 2005)).

The precise mechanisms underlying the effects of the speed of drug delivery on the motivation for cocaine remain to be identified. However, certain potential explanations must be considered. It could be argued that the 5-s groups demonstrated greater motivation to self-administer cocaine during PR testing because they had previously been exposed to larger amounts of the drug. Indeed, before testing under $\mathrm{PR}$, animals in the 5-s condition had taken more cocaine than animals in the 90-s condition. However, the SA of larger amounts of cocaine does not necessarily lead to increased drug intake under a PR schedule, sometimes it is quite the opposite (Morgan et al, 2006). In addition, in the present study, the amount of cocaine taken in the past was dissociable from drug intake during PR testing. For example, the $0.25 \mathrm{mg}-5 \mathrm{~s}$ and $0.5 \mathrm{mg}-90 \mathrm{~s}$ groups had selfadministered similar amounts of cocaine before PR testing (see the two superimposed curves in Figure 3g), yet the $0.25 \mathrm{mg}-5 \mathrm{~s}$ group subsequently took more drug under PR (compare Figure $4 \mathrm{a}$ and $\mathrm{b}$ ). This being said, the possibility that the amount of cocaine consumed by the 5- vs 90-s rats might have influenced breakpoints for the drug cannot be dismissed entirely. Increased cocaine intake can predict increased breakpoints for the drug. For example, compared with rats with a history of limited access to cocaine, rats previously given extended access take much more cocaine and also subsequently show elevated breakpoints for the drug (Paterson and Markou, 2003; Wee et al, 2008). Thus, it remains possible that the rapid delivery of cocaine to the brain might lead to greater motivation to take the drug in part by promoting the intake of increasing amounts of cocaine. Exposing the brain to larger quantities of cocaine, in turn, would presumably promote the neuroplastic changes that underlie excessive motivation for drug. Another potential explanation is that less cocaine reaches the brain when the drug is delivered over $90 \mathrm{~s}$. This is possible, but unlikely. Pharmacokinetic modelling reveals that when cocaine is delivered between 5 and $100 \mathrm{~s}$, brain Cmax does not vary significantly, but the rate of rise of drug levels does (Samaha et al, 2002; Schindler et al, 2009). Brain dopamine levels produced by cocaine are also linearly correlated with brain concentrations of cocaine (Nicolaysen et al, 1988), and varying the speed of intravenous cocaine injection between 5 and $100 \mathrm{~s}$ has no effect on total or peak brain dopamine levels (Ferrario et al, 2008). Finally, there is no difference in self-administration behavior between 5-s and 90-s rats during ShA sessions ((Crombag et al, 2008; Wakabayashi et al, 2010) and present findings), suggesting that similar amounts of cocaine are reaching the brain. It appears, therefore, that something about the temporal dynamics of chronic cocaine delivery to the brain determines the subsequent motivation to take the drug.

Several psychological processes are likely to be involved in the ability of rapidly delivered cocaine to enhance drug intake under a PR schedule of reinforcement. For example, the 5-s groups might have taken more cocaine because they developed greater tolerance to the hedonic and rewarding effects of the drug, thus requiring greater amounts of cocaine to obtain the same subjective effects (Ahmed et al, 2002). However, compared with the 90-s groups, the 5-s groups showed an upward shift in the dose-response curve for cocaine during PR testing (Figure $4 \mathrm{a}$ and $\mathrm{b}$ ), as opposed to the downward shift associated with tolerance (Li et al, 1994). The 5-s groups might also have worked harder for cocaine, because they attributed increased motivational value not only to cocaine but also to cocaine-associated stimuli as well. In both the 5- and 90-s groups, each selfadministered cocaine infusion was accompanied by illumination of a stimulus light, making this light a cocaine cue. Such drug cues can acquire incentive motivational properties of their own and enhance drug-taking behavior (Panlilio et al, 1996). However, discrete environmental cues paired with either 5- or 90-s cocaine injections acquire similar incentive motivational properties (Samaha et al, 2011). Finally, it has been shown that rapid cocaine infusions more readily induce forms of neural plasticity that are linked to increased incentive motivation for the drug (Liu et al, 2005; Samaha et al, 2002; Samaha et al, 2004; Wakabayashi et al, 2010), and this could account for why animals in the 5-s groups both increase their intake during the LgA sessions and evidence greater motivation to obtain cocaine under PR. For example, increasing the speed of intravenous cocaine delivery between 100 and $5 \mathrm{~s}$ (1) more readily induces psychomotor sensitization (Samaha et al, 2002; Samaha et al, 2004), (2) enhances immediate early gene expression in mesocorticolimbic structures (Ferrario et al, 2008; Samaha et al, 2004), and (3) produces more immediate blockade of dopamine reuptake (Samaha et al, 2004; Woolverton and Wang, 2004), dopamine overflow (Ferrario et al, 2008), and heat-producing metabolic activity (Brown and Kiyatkin, 2005) in regions including the nucleus accumbens and ventral tegmental area. Thus, by more readily engaging the neural circuits involved in incentive motivation, rapidly delivered cocaine could promote increased drug consumption as well as increased responding for the drug in the face of rising costs (as modelled here by the PR procedure). 
Consistent with the literature cited above, our findings show that variations in the speed of drug delivery alter the neurobiological impact of cocaine. Following 14 days of cocaine withdrawal, the 5-s rats had normal levels of striatal D2 receptors and enhanced quinpirole-induced GTP $\gamma \mathrm{S}$ binding to D2 receptors compared with cocaine-naive control animals. This is consistent with the work showing that extended access to rapid cocaine injections $(0.4 \mathrm{mg} / \mathrm{kg} /$ infusion, over $1.6 \mathrm{~s}$ ) does not change striatal D2 receptor protein levels but increases the proportion of striatal D2 receptors that are in a high-affinity state for dopamine (Briand et al, 2008). In contrast, a history of chronic selfadministration of slower cocaine injections (90 s) downregulates striatal D2 receptors and also enhances agonistinduced GTP $\gamma$ S binding to caudate-putamen D2 receptors to a greater extent than that seen following the self-administration of rapid cocaine injections (5s). At present, it cannot be determined on which side of the synapse these receptor changes occur, or whether the net effect is a potentiation or a blunting of dopamine-mediated signalling. However, the results suggest that changes in affinity are not simply a consequence of changes in density or vice versa. Changes in receptor density and in agonist affinity did not always occur in the same locations in the caudate-putamen. For example, at $+0.4 \mathrm{~mm}$ relative to Bregma, the $90-\mathrm{s}$ animals had decreased striatal D2 receptor levels (Figure 5) but no change in quinpirole-induced GTP $\gamma \mathrm{S}$ binding to these receptors (Figure 6).

It is important to consider that because the control group used here was not a yoked saline group, we cannot determine how intravenous infusions of fluid delivered at different speeds might contribute to the D2 receptor changes we report. However, just as there were no differences in striatal D2 receptor density between the control $v s 5$-s rats, others have reported no differences in striatal D2 receptor density following yoked saline $v s$ the SA of cocaine delivered over $5 \mathrm{~s}$ (Frankowska et al, 2013). This study also did not include a yoked cocaine group. As such, we cannot exclude the possibility that interaction effects between the speed of cocaine delivery, the pharmacological effects of the drug, and the volitional self-administration of cocaine might have contributed to the observed changes in D2 receptor number and function.

It is not clear how the observed D2 receptor changes might contribute to the effects of the speed of cocaine delivery on the motivation to self-administer the drug. The two effects might not be causally related. Another possibility is that decreases in D2 receptor number and/or increases in D2 agonist affinity in specific caudate-putamen locations modify striatal signalling in ways that protect from excessive motivation to take cocaine. Indeed, we report the novel and surprising finding that striatal D2 receptor levels are decreased and D2 agonist affinity is increased in rats that take only a modest amount of cocaine when given the opportunity to self-administer much more and that are only moderately motivated to lever-press for the drug (ie, the 90-s rats). Changes in D2 density or agonist affinity were either absent or less pronounced in the 5-s rats. As such, it is possible that rapidly injected cocaine leads to greater motivation to obtain the drug in part by preventing forms of D2-related neuroadaptations that protect from compulsive drug use. However, this remains highly speculative, and contradicts a number of findings in the literature. Indeed, reduced striatal D2 receptor availability and increased D2 receptor function are each reported to enhance drug effects that are relevant to addiction. For example, cocaine abusers have reduced striatal D2 receptor availability (Martinez et al, 2004; Volkow et al, 1993; Volkow et al, 1990), and innately low striatal D2 receptor availability is predictive of both increased positive subjective ratings of a psychostimulant such as methylphenidate (Volkow et al, 1999) and enhanced psychomotor sensitization to amphetamine (Tournier et al, 2013). In addition, the D1/D2 receptor agonist pergolide increases craving for cocaine in cocaine abusers (but decreases many of the drug's positive subjective effects in the same subjects (Haney et al, 1998). D2-like agonists can also trigger the reinstatement of extinguished cocaine-seeking behavior in rats (Self et al, 1996) and evoke a behaviorally sensitized psychomotor response in methamphetamine- or cocainetreated rats (Ujike et al, 1990).

In conclusion, the present results demonstrate that the rapid delivery of cocaine leads to greater drug intake and greater motivation to expend physical effort to obtain the drug. The self-administration of rapid $v s$ more sustained cocaine infusions also led to distinct neurobiological profiles, such that striatal D2 receptor density and agonist affinity were altered to a greater extent in animals that had been exposed to slower cocaine injections. We suggest that the rapid uptake of cocaine into the brain might facilitate addiction not simply because it increases the reinforcing or subjective pleasurable effects of the drug but because rapid delivery alters brain motivation circuits in ways that increase the willingness to self-administer the drug in the face of rising costs, leading to pathological drug use.

\section{FUNDING AND DISCLOSURE}

The authors declare no conflict of interest. This research was supported by grants from the Canadian Institutes of Health Research (http://www.cihr-irsc.gc.ca/e/193.html; Grant No. 97841) and the Canada Foundation for Innovation (http://www.innovation.ca/en; Grant No. 24326) to ANS, and a salary award from the Fonds de la Recherche en Santé du Québec (http://www.frsq.gouv.qc.ca/en/index. shtml; Grant No. 16193) to ANS.

\section{ACKNOWLEDGEMENTS}

We thank Miss Anne-Marie Bédard, Mr Karim BouayadGervais and Miss Irina Gheoda for valuable technical assistance. We are grateful to Dr Guy Rousseau for advice on statistical analysis of the data.

\section{REFERENCES}

Abreu ME, Bigelow GE, Fleisher L, Walsh SL (2001). Effect of intravenous injection speed on responses to cocaine and hydromorphone in humans. Psychopharmacology (Berl) 154: 76-84.

Ahmed SH (2012). The science of making drug-addicted animals. Neuroscience 211: 107-125. 
Ahmed SH, Kenny PJ, Koob GF, Markou A (2002). Neurobiological evidence for hedonic allostasis associated with escalating cocaine use. Nat Neurosci 5: 625-626.

Ahmed SH, Koob GF (1998). Transition from moderate to excessive drug intake: change in hedonic set point. Science 282: 298-300.

Badiani A, Robinson TE (2004). Drug-induced neurobehavioral plasticity: the role of environmental context. Behav Pharmacol 15: 327-339.

Balster RL, Schuster CR (1973). Fixed-interval schedule of cocaine reinforcement: effect of dose and infusion duration. J Exp Anal Behav 20: 119-129.

Barrio G, De La Fuente L, Lew C, Royuela L, Bravo MJ, Torrens M (2001). Differences in severity of heroin dependence by route of administration: the importance of length of heroin use. Drug Alcohol Depend 63: 169-177.

Belin D, Balado E, Piazza PV, Deroche-Gamonet V (2009). Pattern of intake and drug craving predict the development of cocaine addiction-like behavior in rats. Biol Psychiatry 65: 863-868.

Briand LA, Flagel SB, Seeman P, Robinson TE (2008). Cocaine selfadministration produces a persistent increase in dopamine D2 high receptors. Eur Neuropsychopharmacol 18: 551-556.

Brown PL, Kiyatkin EA (2005). Brain temperature change and movement activation induced by intravenous cocaine delivered at various injection speeds in rats. Psychopharmacology (Berl) 181: 299-308.

Carpenter MJ, Chutuape MA, Stitzer ML (1998). Heroin snorters vs injectors: comparison on drug use and treatment outcome in age-matched samples. Drug Alcohol Depend 53: 11-15.

Crombag HS, Ferrario CR, Robinson TE (2008). The rate of intravenous cocaine or amphetamine delivery does not influence drug-taking and drug-seeking behavior in rats. Pharmacol Biochem Behav 90: 797-804.

de Wit H, Dudish S, Ambre J (1993). Subjective and behavioral effects of diazepam depend on its rate of onset. Psychopharmacology (Berl) 112: 324-330.

Deroche-Gamonet V, Belin D, Piazza PV (2004). Evidence for addiction-like behavior in the rat. Science 305: 1014-1017.

Ferrario CR, Robinson TE (2007). Amphetamine pretreatment accelerates the subsequent escalation of cocaine self-administration behavior. Eur Neuropsychopharmacol 17: 352-357.

Ferrario CR, Shou M, Samaha AN, Watson CJ, Kennedy RT, Robinson TE (2008). The rate of intravenous cocaine administration alters c-fos mRNA expression and the temporal dynamics of dopamine, but not glutamate, overflow in the striatum. Brain Res 1209: 151-156.

Ferri CP, Gossop M (1999). Route of cocaine administration: patterns of use and problems among a Brazilian sample. Addict Behav 24: 815-821.

Frankowska M, Marcellino D, Adamczyk P, Filip M, Fuxe K (2013). Effects of cocaine self-administration and extinction on D2 -like and $\mathrm{A} 2 \mathrm{~A}$ receptor recognition and D2 -like/Gi protein coupling in rat striatum. Addiction biology 18: 455-466.

Gossop M, Griffiths P, Powis B, Strang J (1992). Severity of dependence and route of administration of heroin, cocaine and amphetamines. Br J Addict 87: 1527-1536.

Haney M, Foltin RW, Fischman MW (1998). Effects of pergolide on intravenous cocaine self-administration in men and women. Psychopharmacology (Berl) 137: 15-24.

Hatsukami DK, Fischman MW (1996). Crack cocaine and cocaine hydrochloride. Are the differences myth or reality? JAMA 276: $1580-1588$.

Hughes JR (1989). Dependence potential and abuse liability of nicotine replacement therapies. Biomed Pharmacother 43: 11-17.

Kalivas PW, Volkow ND (2005). The neural basis of addiction: a pathology of motivation and choice. Am J Psychiatry 162: 1403-1413.
Kato S, Wakasa Y, Yanagita T (1987). Relationship between minimum reinforcing doses and injection speed in cocaine and pentobarbital self-administration in crab-eating monkeys. Pharmacol Biochem Behav 28: 407-410.

Kippin TE, Fuchs RA, See RE (2006). Contributions of prolonged contingent and noncontingent cocaine exposure to enhanced reinstatement of cocaine seeking in rats. Psychopharmacology (Berl) 187: 60-67.

Kollins SH, Rush CR, Pazzaglia PJ, Ali JA (1998). Comparison of acute behavioral effects of sustained-release and immediaterelease methylphenidate. Exp Clin Psychopharmacol 6: 367-374.

Le Moal M (2009). Drug abuse: vulnerability and transition to addiction. Pharmacopsychiatry 42(Suppl 1): S42-S55.

Li D, Depoortere R, Emmett-Oglesby M (1994). Tolerance to the reinforcing effects of cocaine in a progressive ratio paradigm. Psychopharmacology 116: 326-332.

Liu Y, Roberts DC, Morgan D (2005). Sensitization of the reinforcing effects of self-administered cocaine in rats: effects of dose and intravenous injection speed. Eur J Neurosci 22: $195-200$

Maheux J, St-Hilaire M, Voyer D, Tirotta E, Borrelli E, Rouillard C et al (2012). Dopamine $\mathrm{D}(2)$ antagonist-induced striatal Nur77 expression requires activation of mGlu5 receptors by cortical afferents. Front Pharmacol 3: 153.

Mantsch JR, Ho A, Schlussman SD, Kreek MJ (2001). Predictable individual differences in the initiation of cocaine self-administration by rats under extended-access conditions are dosedependent. Psychopharmacology (Berl) 157: 31-39.

Mantsch JR, Yuferov V, Mathieu-Kia AM, Ho A, Kreek MJ (2004). Effects of extended access to high $v s$ low cocaine doses on selfadministration, cocaine-induced reinstatement and brain mRNA levels in rats. Psychopharmacology (Berl) 175: 26-36.

Martinez D, Broft A, Foltin RW, Slifstein M, Hwang DR, Huang Y et al (2004). Cocaine dependence and $\mathrm{d} 2$ receptor availability in the functional subdivisions of the striatum: relationship with cocaine-seeking behavior. Neuropsychopharmacology 29: 1190-1202.

Morgan D, Liu Y, Roberts DC (2006). Rapid and persistent sensitization to the reinforcing effects of cocaine. Neuropsychopharmacology 31: 121-128.

Nicolaysen LC, Pan H-T, Justice JB Jr (1988). Extracellular cocaine and dopamine concentrations are linearly related in rat striatum. Brain Res 456: 317-323.

O'Brien CP (2008). Review. Evidence-based treatments of addiction. Philos Trans R Soc Lond B Biol Sci 363: 3277-3286.

Panlilio LV, Goldberg SR, Gilman JP, Jufer R, Cone EJ, Schindler CW (1998). Effects of delivery rate and non-contingent infusion of cocaine on cocaine self-administration in rhesus monkeys. Psychopharmacology (Berl) 137: 253-258.

Panlilio LV, Weiss SJ, Schindler CW (1996). Cocaine selfadministration increased by compounding discriminative stimuli. Psychopharmacology (Berl) 125: 202-208.

Paterson NE, Markou A (2003). Increased motivation for selfadministered cocaine after escalated cocaine intake. Neuroreport 14: 2229-2232.

Paxinos G, Watson C (1986). The rat brain in stereotaxic coordinates. 2nd edn. Academic: New York, NY, USA.

Pickens R, Dougherty J, Thompson T (1969). Effects of volume and duration of infusion on cocaine reinforcement with concurrent activity recording. In: NAS-NRC (ed) Minutes of the Meeting of the Committee on Problems of Drug Dependence, Washington, DC, USA, pp 5805-5811.

Rawson RA, Gonzales R, Marinelli-Casey P, Ang A (2007). Methamphetamine dependence: a closer look at treatment response and clinical characteristics associated with route of administration in outpatient treatment. Am J Addict 16: 291-299. 
Richardson NR, Roberts DC (1996). Progressive ratio schedules in drug self-administration studies in rats: a method to evaluate reinforcing efficacy. J Neurosci Methods 66: 1-11.

Roberts DC, Loh EA, Vickers G (1989). Self-administration of cocaine on a progressive ratio schedule in rats: dose-response relationship and effect of haloperidol pretreatment. Psychopharmacology (Berl) 97: 535-538.

Roberts DC, Morgan D, Liu Y (2007). How to make a rat addicted to cocaine. Prog Neuropsychopharmacol Biol Psychiatry 31: 1614-1624.

Robinson TE, Berridge KC (1993). The neural basis of drug craving: an incentive-sensitization theory of addiction. Brain Res Brain Res Rev 18: 247-291.

Samaha AN, Li Y, Robinson TE (2002). The rate of intravenous cocaine administration determines susceptibility to sensitization. J Neurosci 22: 3244-3250.

Samaha AN, Mallet N, Ferguson SM, Gonon F, Robinson TE (2004). The rate of cocaine administration alters gene regulation and behavioral plasticity: implications for addiction. J Neurosci 24: 6362-6370.

Samaha AN, Minogianis EA, Nachar W (2011). Cues paired with either rapid or slower self-administered cocaine injections acquire similar conditioned rewarding properties. PLoS One 6: e26481.

Samaha AN, Robinson TE (2005). Why does the rapid delivery of drugs to the brain promote addiction? Trends Pharmacol Sci 26: 82-87.

Schindler CW, Cogan ES, Thorndike EB, Panlilio LV (2011). Rapid delivery of cocaine facilitates acquisition of self-administration in rats: An effect masked by paired stimuli. Pharmacol Biochem Behav 99: 301-306.

Schindler CW, Panlilio LV, Thorndike EB (2009). Effect of rate of delivery of intravenous cocaine on self-administration in rats. Pharmacol Biochem Behav 93: 375-381.

Self DW, Barnhart WJ, Lehman DA, Nestler EJ (1996). Opposite modulation of cocaine-seeking behavior by D1- and D2-like dopamine receptor agonists. Science 271: 1586-1589.

Sim LJ, Selley DE, Childers SR (1995). In vitro autoradiography of receptor-activated $\mathrm{G}$ proteins in rat brain by agonist-stimulated guanylyl 5'-[gamma-[35S]thio]-triphosphate binding. Proc Natl Acad Sci USA 92: 7242-7246.

Sorge RE, Clarke PB (2009). Rats self-administer intravenous nicotine delivered in a novel smoking-relevant procedure: effects of dopamine antagonists. J Pharmacol Exp Ther 330: 633-640.

Sovago J, Makkai B, Gulyas B, Hall H (2005). Autoradiographic mapping of dopamine-D2/D3 receptor stimulated [35S]
GTPgammaS binding in the human brain. Eur J Neurosci 22: 65-71.

Tournier BB, Steimer T, Millet P, Moulin-Sallanon M, Vallet P, Ibanez $\mathrm{V}$ et al (2013). Innately low D2 receptor availability is associated with high novelty-seeking and enhanced behavioural sensitization to amphetamine. Int J Neuropsychopharmacol (e-pub ahead of print).

Ujike H, Akiyama K, Otsuki S (1990). D-2 but not D-1 dopamine agonists produce augmented behavioral response in rats after subchronic treatment with methamphetamine or cocaine. Psychopharmacology (Berl) 102: 459-464.

Vanderschuren LJ, Everitt BJ (2004). Drug seeking becomes compulsive after prolonged cocaine self-administration. Science 305: 1017-1019.

Volkow ND, Fowler JS, Wang GJ, Hitzemann R, Logan J, Schlyer DJ et al (1993). Decreased dopamine D2 receptor availability is associated with reduced frontal metabolism in cocaine abusers. Synapse 14: 169-177.

Volkow ND, Fowler JS, Wolf AP, Schlyer D, Shiue CY, Alpert R et al (1990). Effects of chronic cocaine abuse on postsynaptic dopamine receptors. Am J Psychiatry 147: 719-724.

Volkow ND, Wang GJ, Fowler JS, Logan J, Gatley SJ, Gifford A et al (1999). Prediction of reinforcing responses to psychostimulants in humans by brain dopamine D2 receptor levels. Am J Psychiatry 156: 1440-1443.

Wakabayashi KT, Weiss MJ, Pickup KN, Robinson TE (2010). Rats markedly escalate their intake and show a persistent susceptibility to reinstatement only when cocaine is injected rapidly. J Neurosci 30: 11346-11355.

Wakasa Y, Takada K, Yanagita T (1995). Reinforcing effect as a function of infusion speed in intravenous self-administration of nicotine in rhesus monkeys. Nihon Shinkei Seishin Yakurigaku Zasshi 15: 53-59.

Wee S, Mandyam CD, Lekic DM, Koob GF (2008). Alpha 1noradrenergic system role in increased motivation for cocaine intake in rats with prolonged access. Eur Neuropsychopharmacol 18: 303-311.

Wee S, Specio SE, Koob GF (2007). Effects of dose and session duration on cocaine self-administration in rats. J Pharmacol Exp Ther 320: 1134-1143.

Winger G, Hofmann GG, Woods JH (1992). A Handbook on Drug and Alcohol Abuse: the Biomedical Aspects. Oxford UP: New York, NY, USA.

Woolverton WL, Wang Z (2004). Relationship between injection duration, transporter occupancy and reinforcing strength of cocaine. Eur J Pharmacol 486: 251-257.

Supplementary Information accompanies the paper on the Neuropsychopharmacology website (http://www.nature.com/npp) 